\title{
PERLINDUNGAN HUKUM DAN KEDUDUKAN PEMEGANG HAK TERHADAP PEMBLOKIRAN SERTIFIKAT HAK ATAS TANAH OLEH KANTOR PERTANAHAN
}

\author{
Jazillatul Ulfa, Fitika Andraini \\ Fakultas Hukum, Universitas Stikubank (UNISBANK) Semarang \\ Email: jazilulfa@gmail.com, fitika@edu.unisbank.ac.id
}

\begin{abstract}
ABSTRAK
Bumi , Air, dan ruang angkasa serta kekayaan alam yang terkandung di dalamnya di kuasai oleh Negara merupakan karunia Tuhan Yang Maha Esa yang fungsi dan pemanfaatannya untuk kemakmuran rakyat. Tanah Bagi Bangsa Indonesia merupakan sumber penghidupan dan diatur dalam ketentuan UU.Undang-Undang Pokok Agraria No 5 Tahun 1990 meletakkan dasar tentang memberikan kepastian hukum terhadap hak-hak atas tanah bagi rakyat Indonesia. Kepastian Hukum ini didapat setelah proses pendaftaran tanah.. Hak- hak atas tanah yang telah memiliki kepastian hukum dapat di alihkan ataupun beralih. namun dalam prosesnya sengketa mengenai hak atas tanah masih banyak terjadi di masyarakat. Pemblokiran Sertifikat Hak Atas Tanah diambil sebagai langkah administratif dalam proses penyelesaian sengketa, namun adanya jangka waktu yang hanya 30 hari pencatatan pemblokiran Peru diketahui bagaimana faktorfaktor pemblokiran tanah, bagaimana mengetahui kedudukan pemegang sertifikat Hak Atas Tanah saat di lakukan pemblokian dan saat jangka waktu 30 hari pemblokiran habis namun sengketa belum selesai. Tipe penelitian yang digunakan penulis adalah yuridis normatif dan spesifikasi penelitian deskriptif analitis dengan pengumpulan data secara studi pustaka dan wawancara yang disajikan dengan cara deskriptif dan dianalisis secara diskriptif kualitatif.

Hasil Penelitian dan analisis data yang dilakukan adalah dapat diketahui faktor-faktor yang menyebabkan pemblokiran terhadap Sertifikat Hak Atas Tanah yaitu : a. Pembagian Harta Gono-Gini, b. Pemegang Hak Atas Tanah tidak Beritikad Baik,c. Pembagian Harta Warisan, d. Sertifikat Hilang, e. Adanya penyidikan dari Pihak Kepolisian, f. Hak Atas Tanah disita jurusita Panitia Urusan Piutang Negara (PUPN) dalam kaitan pelunasan Piutang Negara. Perlindungan hukum \& kedudukan Pemegang Sertifikat Hak Atas Tanah saat di lakukan pemblokian adalah bagi pemegang hak tidak dapat melakukan perbuatan hukum kepada tanah yang di blokir selama 30 hari semenjak pencatatan blokir dilakukan, pasal 19 UUUPA/ PP 241997 tentang pendaftaran tidak akan hilang. Kepastian hukum pemegang hak tetap melekat padanya selama belum ada peralihan hak atas tanah yang dimilikinya.Jika saat jangka waktu 30 hari pemblokiran habis namun sengketa belum selesai dilakukan pencatatan pemblokiran tidak akan hapus demi hukum dan akan tetap berlaku selama tidak ada permohonan cabut oleh pemohon ataupun ketentuan-ketentuan lain yang menjadi alasan hapusnya blokir sesuai dengan pasal pasal 14 Peraturan Mentri ATR/Kepala Badan Pertanahan Nasional
\end{abstract}


No.13 tahun 2017 tentang Tata Cara Blokir dan Sita, hal ini disebabkan karena di Kantor Pertanahan (Semarang) belum ada sistem yang dapat mengidentifikasi ataupun menyaring pemblokiran yang sudah daluwarsa.

\section{Kata Kunci: Pendaftaran Tanah, Kepastian Hukum, Pemegang Hak, Pemblokiran Sertifikat Hak Atas Tanah, Kedudukan pemegang hak}

ABSTRACT

Earth, water and space as well as the natural resources contained therein under the control of the State are gifts from God Almighty whose functions and uses are for the prosperity of the people. Land for the Indonesian Nation is a source of livelihood and is regulated in the provisions of the Law. The Basic Agrarian Law No. 5 of 1990 lays the foundation on providing legal certainty for land rights for the Indonesian people. Legal certainty is obtained after the land registration process. Land rights that have legal certainty can be transferred or transferred. however, in the process, disputes over land rights still occur in the community. Blocking of Land Rights Certificates is taken as an administrative step in the dispute resolution process, but there is a period of only 30 days to record the blocking of Peru, it is known how the factors of land blocking, how to know the position of the holder of the Land Rights certificate when the block is being blocked and when the period is 30 blocking day is over but the dispute has not been resolved. The type of research used by the writer is juridical normative and descriptive analytical research specification by collecting data by means of literature study and interviews which are presented in a descriptive manner and analyzed in a descriptive qualitative manner.

The results of the research and data analysis carried out show the factors that cause the blocking of Land Rights Certificates, namely: a. Gono-Gini distribution of assets, b. Land Rights Holders do not have good faith, c. Distribution of Inheritance, $d$. Lost Certificate, e. There is an investigation by the Police, f. Land rights confiscated by the State Receivables Affairs Committee (PUPN) in connection with the settlement of State Receivables. Legal protection \& the position of the Land Rights Certificate Holder when the blockage is carried out is that the right holder cannot take legal action against the blocked land for 30 days after the block registration was carried out, article 19 UUUPA / PP 241997 regarding registration will not be lost The legal certainty of the rights holder remains attached to it as long as there has been no transfer of rights to the land they own. If the 30 day period of blocking is over but the dispute has not been completed, the blocking will not be removed by law and will remain in effect as long as there is no request for revocation by the applicant or the provisions -Other provisions which become the reasons for the removal of the block in accordance with article 14 of the Regulation of the Minister of ATR / Head of the National Land Agency No.13 of 2017 concerning the Procedure for Blocking and Confiscation, this is because in the Land Office (Semarang) there is no system that can identify or filter out expired blocks. 
Keywords: Land Registration, Legal Certainty, Rightsholders, Blocking of Land Rights Certificates, Position of Rightsholders 


\section{Pendahuluan}

Dalam UUPA hal mendasar yang diatur adalah tentang kepastian hukum dari pendaftaran tanah. Dalam pasal 19 juga menyebutkan bahwa : "untuk menjamin kepastian hukum oleh pemerintah diadakan pendaftaran tanah di seleluruh wilayah Republik Indonesia menurut ketentuan-ketentuan yang diatur dengan Peraturan Pemerintah" ${ }^{\text {.Dengan }}$ diadakan pendaftaran tanah ini pemerintah berharap akan adanya kepastian hukum bagi pemegang hak atas tanah dan meminimalisir adanya sengketa. Dalam UUPA pasal 16 ayat (1) jo pasal 53 terdapat jenis jenis hak atas tanah. Hakhak atas tanah yang sudah didaftarkan tersebut telah memiliki kepastian hukum dan dapat dialihkan ataupun beralih. Namun dalam pelaksanaan pendaftaran maupun peralihan hak atas tanah masih dapat terjadi sengketa hak-hak atas tanah yang terjadi di masyarakat.

Hal inilah yang mendasari adanya permohonan pemblokiran atas Sertifikat Hak Atas Tanah yang di lakukan di kantor pertanahan sebagai salah satu upaya administratif untuk mengantisipasi agar Sertifikat Hak Atas Tanah Tersebut tidak dapat dilakukan perbuatan hukum. Permohonan pemblokiran hak atas tanah tersebut dapat dilakukan oleh orang perorangan, Badan Hukum dan pihak Pengadilan. Dalam permohonan pemblokiran pemohon harus mencantumkan alasan yang jelas dan para pihak harus bersedia dilaksanakan pemeriksan atas permohonan yang di ajukan. Dengan di lakukan pemblokiran akan berakibat pada pemegang hak atas tanah yang tidak dapat bertindak bebas

\footnotetext{
1 Undang-Undang Nomor 5 Tahun 1960 tentang Peraturan Dasar Pokok -Pokok Agraria Pasal 19
}

atas tanah yang dimilikinya sekalipun sudah bersertifikat hak milik selama 30 hari sejak dicatatkan blokir atas tanah tersebut, pemegang hak tidak dapat melakukan perbuatan hukum terhadap hak atas tanah yang dimilikinya, ketentuan tersebut sesuai dengan yang disebutkan dalam pasal 13 Peraturan Mentri ATR/Kepala Badan Pertanahan Nasional No.13 tahun 2017 tentang Tata Cara Blokir dan Sita.

Sebagai langkah administratif, pemblokiran dapat menjadi salah satu alternatif yang sangat baik untuk mencegah adanya peralihan hak ataupun pembebanan hak, namun dengan adanya ketetentuan jangka waktu yang hanya 30 hari dirasa akan merugikan pihak pemegang hak apabila setelah selesai batas waktu pembokiran tersebut sengketa yang terjadi masih berlangsung dan belum ada penetapan maupun putusan. Karena dalam Peraturan Mentri Agraria dan Tata Ruang / Kepala BPN No .13 Tahun 2017 tentang Tata Cara Blokir dan Sita perpanjangan pemblokiran hanya dapat dilakukan karena adanya perintah pengadilan berupa penetapan atau putusan.

Setelah jangka waktu 30 hari selesai dan tidak ada perpanjangan berupa putusan ataupun penetapan dari pengadilan maka blokir hapus demi hukum. Maka dari itu penulis ingin meneliti apakah faktor-faktor pemblokiran tanah serta kedudukan pemegang hak atas tanah saat dilaksanakan pemblokiran sertifikat Hak Atas Tanah dan setelah jangka waktu 30 hari pemblokiran habis namun sengketa belum selesai. Berdasarkan dengan uraian di atas maka penulis ingin meneliti permasalahan mengenai Kedudukan Pemegang Hak Terhadap Pemblokiran Sertifikat Hak Atas 
Tanah Oleh Kantor Pertanahan di Kota Semarang

\section{Perumusan Masalah}

1. Faktor-faktor apa saja yang menyebabkan pemblokiran terhadap Sertifikat Hak Atas Tanah?

2. Bagaimana kedudukan Pemegang Sertifikat Hak Atas Tanah saat di lakukan pemblokian dan saat jangka waktu 30 hari pemblokiran habis namun sengketa belum selesai?

\section{Metode Penelitian}

Metode pendekatan yang digunakan dalam penelitian ini adalah tipe penelitian yuridis normatif. Metode penelitian yuridis normatif adalah suatu penelitian yang secara deduktif dimulai analisis terhadap pasal-pasal dalam peraturan terhadap permasalahan diatas. Spesifikasi penelitian yang dipergunakan adalah deskriptif analitis, yaitu suatu metode yang dipakai untuk menggambarkan suatu kondisi atau keadaan yang sedang berlangsung yang tujuannya agar dapat memberikan data mengenai objek penelitian sehingga mampu menggali halhal yang bersifat ideal, kemudian dianalisis berdasarkan teori hukum atau peraturan perundang-undangan yang berlaku ${ }^{2}$.

Kementrian Agraria dan Tata Ruang/BPN Kota Semarang yang beralamat di Jalan Ki Mangunsarkoro No.23, Karangkidul, Kecamatan Semarang Tengah, Kota Semarang, Jawa Tengah 50241.Data yang diperlukan dalam penelitian ini yaitu Data Sekunder dan Data Primer Metode penyajian data

\footnotetext{
2 Zainudin ali, Metode Penelitia Hukum, Sinar Grafiak, 2010, hal 5
}

dalam penelitian ini dilakukan dengan cara deskriptif yaitu menjelaskan atau menggambarkan kenyataan - kenyataan yang terjadi pada obyek penelitian secara tepat dan jelas untuk memperoleh kejelasan tentang masalah yang muncul. Data yang diperoleh akan dianalisis secara diskriptif kualitatif, yaitu menganalisis hasil penelitian yang diperoleh baik dari observasi, wawancara, maupun studi kepustakaan yang kemudian dituangkan dalam bentuk uraian yang logis dan sistematis. Pemilihan terhadap analisis ini karena data utama yang digunakan bukan dalam bentuk angka-angka yang dapat dilakukan pengukuran.

\section{Pembahasan}

\section{Faktor-faktor Penyebab Pemblokiran}

\section{a. Pembagian Harta Gono-gini}

Pemblokiran sertifikat dilakukan sebagai langkah pengamanan administratif terhadap tanah yang dimiliki bersama oleh sepasang suami dan istri. Peblokiran ini dilakukan dengan alasan tanah tersebut belum dibagi rata setelah mereka bercerai.

b. Pemegang Hak Atas Tanah tidak Beritikad Baik.

Pemegang hak dikatakan tidak beritikad baik dikarenakan pemegang hak tidak menyerahkan Sertifikat Hak Atas Tanah yang telah dijadikan bahan jaminan gadai di Bank dan pemegang Hak tersebut wanprestasi serta apabila Pemegang Hak atas tanah ini menjaminakan kembali sertifikat tersebut kepada Bank lain. Maka pihak Bank dapat mengajukan pemblokiran dengan alasan tersebut.

\section{c. Pembagian Harta Warisan}

Pemblokiran ini biasanya dilakukan untuk pengamanan bagi seluruh ahli waris agar tanah yang dimohonkan blokir tidak dialihkan maupun diagungkan oleh salah 
satu atau lebih ahli waris sebelum pembagian warisan di laksanakan. Dalam hal pembagian harta warisan ini siapaun ahli waris dapat mengajukan permohonan pemblokiran apabila dapat membuktikan bahwa tanah tersebut benar milik pewaris yang berhubungan darah dengan ahli waris.

\section{d. Sertifikat Hilang}

Pemblokiran juga dapat dilakukan atas dasar permohonan pemlik hak atas tanah yang sertifikatnya hilang, sehingga pemiik mengajukan permohonan pemblokiran terhadap sertifikat Hak Atas Tanah Tersebut. Hal ini dilakukan karena pemilik Hak Atas Tanah khawatir Sertifikat tersebut digunakan oleh pihakpihak yang tidak bertanggung jawab. Apabila Sertifikat Tanah tersebut ditemukan maka pemohon pemblokiran tersebut harus mencabut blokir tersebut dengan permohonan pencabutan blokir secara tertulis Kepada Kepala Kantor Pertanahan. Dengan diadakannya pencabutan maka telah dapat dilakukan perbuatan hukum terhadap sertifikat tersebut.

\section{e. Adanya penyidikan dari Pihak Kepolisian \\ Berdasarkan salinan resmi surat} penyitaan yang dikeluarkan oleh penyidik biasanya terjadi jika tanah tersebut merupakan barang bukti dari sebuah penyidikan dan penuntutan sebuah perkara pidana. Contohnya saja kasus tindak pidana korupsi dan tindak pidana pencucian uang,. Pencatatan pemblokiran ini bertujuan untuk menjamin tanah tersebut tidak dilakukan perbuatan hukum apapun dan oleh siapapun demi kepentingan penegakan keadilan oleh instansi yang berwenang.

f. Hak Atas Tanah disita jurusita Panitia Urusan Piutang Negara (PUPN) dalam kaitan pelunasan Piutang Negara.

Pemblokiran sertifikat hak atas tanah dapat dilakukan atas dasar tanah tersebut menjadi sengketa yang dilanjutkan dengan sita jaminan yang dimohonkan oleh Hakim Pengadilan kepada Kantor Pertanahan untuk diblokir hak atas tanah tersebut sampai adanya putusan pengadilan. Selain itu, hak atas tanah debitur/penjamin hutang dalam kaitan pelunasan piutang negara dapat disita oleh jurusita Panitia Urusan Piutang Negara (PUPN) pada Kantor Lelang Negara, dalam hal ini Direktorat Jenderal Kekayaan Negara (DJKN) melalui Kantor Pelayanan Kekayaan Negara dan Lelang (KPKNL).

Faktor -faktor diatas adalah alasan diajukannya permohonan blokir di kantor pertanahan kota semarang. Namun kantor pertanahan kota semarang tidak memberikan rincian data mengenai seberapa banyak pemblokiran yang dimohonkan dengan alasan faktor-faktor tersebut. Sehingga tidak dapat mengidentifikasi berapa banyak permohonan pemblokiran oleh masingmasing faktor tersebut. Sistematika Pengajuan Permohonan Pemblokiran Dalam mengajukan permohonan pencatatan blokir langkah pertama yang harus dilakukan adalah pemohon harus menyerahkan dokumen yang Lengkap Sesuai Dengan Pasal 6 Dan 7 Peraturan Mentri ATR/Kepala Badan Pertanahan Nasional No. 13 tahun 2017 tentang cara blokir dan sita kemudian Dokumendokumen tersebut di masukkan ke dalam map dan diajukan ke loket pelayanan yang berwenang menerima permohonan di kantor pertanahan, pemohon harus membayar biaya pendaftaran ke loket pembayaran sesuai dengan ketentuan 
Peraturan Pemerintah Nomor 128 Tahun 2015 Tentang jenis dan Tarif Atas Penerimaan Negara Bukan Pajak yaitu sebesar Rp.50.000,-. Berkas-berkas yang sudah masuk ke Kantor Pertanahan akan di lakukan pengkajian oleh Seksi Penangan Masalah dan Pengendalian Pertanahan.Selanjutnya Seksi Penangan Masalah dan Pengendalian Pertanahan akan meminjam Buku Tanah yang berkaitan dengan tanah yang dimohonkan pemblokiran untuk dilihat ada atau tidaknya Hak Tanggungan yang membebani Sertifikat tersebut karena dalam pemblokiran Sertifikat Hak Atas Tanah yang sudah di bebani Hak Taggungan tidak dapat di mohonkan pemblokiran kecuali oleh Bank dengan syarat Bank tersebut harus benar-benar membuktikan bahwa alasan permohonan pemblokiran sertifikat tersebut kuat dan sah.

Berkas permohonan blokir yang sudah dianalisis dan dikaji yang sudah memenui syarat akan dinyatakan bahwa permohonan pemblokiran diterima kemudian akan di lakukan Pencatatan blokir pada Buku Tanah oleh Pelaksanaan Seksi Pemeliharaan Data Hak Tanah dan Pembinaan PPAT. Pencatatan blokir ini berisikan tulisan pada tanggal...dan jam...menit...detik...telah dicatat blokir berdasarkan permohonan saudara... dengan alasan... “/”. Kemudian pencatatan blokir tersebut dibubuhi paraf atau tanda tangan oleh Kepala Kantor Pertanahan. Setelah pencatatan blokir di buku tanah tersebut Kantor Pertanahan memberikan surat balasan yang sudah dianda tangan atau paraf dari Kepala Kantor Pertanahan sebagai tanda persetujuan pencatatan blokir untuk pemohon yang memuat tentang penjelasan bahwa blokir telah diterima, surat balasan yang sudah dianda tangan atau paraf dari Kepala Kantor Pertanahan sebagai tanda persetujuan pencatatan blokir. Apabila permohonan pemblokiran ditolak oleh Kantor Pertanahan, maka Kantor Pertanahan juga akan memberikan surat balasan kepada pemohon yang isinya terkait penolakan pembloiran serta alasan yang mendasari penolakan tersebut.

Namun dalam proses permohonan maupun pelaksanaan pemblokira masih banyak terjadi kendala yang dialami yaitu:

1. Tidak kooperatifnya para pihak yang bersangkutan baik itu pemohon maupun pihak lain yang ikut bersengketa.

2. Tidak adanya perintah dari pengadilan untuk pemblokiran terhadap data fisik maupun data yuridis tanah yang disengketakan.

3. Kurangnya dokumen pendukung pemblokiran yang menunjukan bukti kepemilkan berupa sertifikat asli dan/atau bukti kepemilikan lainnya

Kedudukan Pemegang sertifikat hak atas tanah saat di lakukan pemblokian dan saat jangka waktu $\mathbf{3 0}$ hari pemblokiran habis namun sengketa belum selesai.

Kedudukan Pemegang sertifikat hak atas tanah saat di lakukan pemblokian

Dalam pasal 19 Undang-Undang Pokok Agraria menyebutkan bahwa : "untuk menjamin kepastian hukum oleh pemerintah diadakan pendaftaran tanah di seleluruh wilayah Republik Indonesia menurut ketentuan-ketentuan yang diatur dengan Peraturan Pemerintah" ini artinya bahwa pemegang hak memiliki kepastian hukum atas tanah yang menjadi haknya. Dalam Peraturan Pemerintah no 24 Tahun 1997 tentang pendaftara tanah pasal 3 huruf (a) juga menyebutkan bahwa 
"pendaftaran tanah bertujuan untuk memberikan kepastian dan perlindungan hukum kepada pemegang hak atas suatu bidang tanah, satuan rumah susun dan hak-hak lain yang terdaftar agar dengan mudah dirinya sebagai pemegang hak yang bersangkutan" Kepasitan hukum ini menjadikan pemegang hak bebas dalam melakukan perbuatan hukum terhadap tanah yang dimilikinya. Namun dengan diadakannya pemblokiran ini menyebabkan pemegang hak tidak dapat melakukan perbuatan hukum kepada tanah yang di blokir baik itu peralihan, pembebanan ataupun perbuatan hukum lainnya selama 30 hari semenjak pencatatan blokir dilakukan.

Kepastian hukum yang didapat atas dasar pendaftran tanah sesuai pasal 19 Undang-Undang Pokok Agraria jo PP no 24 tahun 1997 tentang pendaftaran tanah tetap melekat kepada pemegang hak selama kepemilikan hak atas tanah tersebut tidak dialihkan maupun beralih, pemblokiran tidak akan menyebabkan kepastian hukum tersebut itu hilang, namun meskipun kepastian hukum tetap melekat kepada pemegang hak atas tanah, tanah tersebut untuk sementara tidak dapat dilakukan perbuatan hukum. Hal ini juga bertujuan untuk melindungi pemegang Hak Atas Tanah. Jadi untuk kepastian Hak Atas Tanah tidak akan berubah ataupun hilang dan tetap melekat kepada Pemegang Hak Atas Tanah namun untuk sementara Pemegang Hak tidak dapat melakukan Perbuatan Hukum terhadap tanah yang dimilikinya.
Kedudukan Pemegang sertifikat hak atas tanah saat jangka waktu 30 hari pemblokiran habis namun sengketa belum selesai

Ketentuan 30 hari masa pemblokiran terdapat dalam pasal 13 Peraturan Mentri ATR/Kepala Badan Pertanahan Nasional No. 13 tahun 2017 tentang cara blokir dan sita menyebutkan bahwa Catatan blokir oleh perorangan atau badan hukum berlaku jangka waktu 30 ( tiga puluh ) hari kalender terhitung sejak tanggal pencatatan blokir dan hanya dapat diperpanjang dengan adanya perintah pengadilan berupa penetapan atau putusan.

Sedangkan dalam pasal 14 Peraturan Mentri ATR/Kepala Badan Pertanahan Nasional No. 13 tahun 2017 tentang cara blokir dan sita adalah Catatan blokir oleh penegak hukum berlaku sampai dengan dihentikannya kasusu pidana yang sedang dalam penyidikan dan penuntutan, atau sampai dengan dihapusnya pemblokiran oleh penyidik yang bersangkutan. Ini artinya setelah masa 30 hari pencatatan blokir bagi perorangan dan Badan Hukum akan hapus dengan sendirinya apabila tidak ada putusan maupun penetapan oleh pengadilan. Dan bagi penegak hukum berlaku sampai dengan dihentikannya kasus pidana.

Namun dalam kenyataan di lapang pemblokiran bagi perorangan ataupun Badan Hukum tidak akan terhapus dengan sendirinya setelah masa 30 hari pencatatan blokir, hal ini dikarenakan pada kantor Pertanahan Kota Semarang belum ada system pendukung untuk menyaring dan mengidentifikasi pencatatan Pemblokiran yang telah habis masa 30 hari. Pencatatan pemblokiran oleh perorangan atau Badan Hukum akan tetap bejalan selama tidak ada pencabutan oleh pemohon ataupun 
pencabutan oleh Kantor Pertanahan dana untuk Penegak Hukum berlaku sampai dengan dihentikannya kasus pidana yang sedang dalam penyidikan dan penuntutan, atau sampai dengan dihapusnya pemblokiran oleh penyidik yang bersangkutan sesuai dengan ketentuan yang terdapat pada pasal 14 Peraturan Mentri ATR/Kepala Badan Pertanahan Nasional No. 13 tahun 2017 tentang cara blokir dan sita yaitu Pecatatan blokir oleh penegak hukum. Masa 30 hari yang tercantum dalam Peraturan Mentri ATR/Kepala Badan Pertanahan Nasional No. 13 tahun 2017 tentang cara blokir dan sita sangat tidak efektif karena dalam praktiknya masa 30 hari tidak berfungsi dan tidak berlaku pada kenyataannya.

Dalam peraturan tersebut tidak dijelaskan alasan mengapa pemblokiran hanya berlaku 30 hari sehingga tidak ada kejelasan tentang mengapa masa blokir hanya 30 hari. Selain jangka waktu yang telah habis pencatatan blokir juga dapat hapus karena hal-hal berikut :

a. Pihak yang memohon blokir telah mencabut permintaanya sebelum jangka waktu berakhir

b. Kepala Kantor Pertanahan menghapus sebelum jangka waktu berakhir

c. Ada perintah pengadilan berupa putusan atau penetapan

d. Kasus pidana yang sedang dalam penyidikan dihentikan

e. Penyidik mengajukan penghapusan catatan blokir Kasus pertanahan yang tidak di perkarakan di pengadilan seperti sertifikat hilang akan tetap dicatatan pemblokiran selama pemohon tidak mencabut pemblokiran tersebut. Jadi dalam praktiknya waktu 30 hari pencatatan pemblokiran tersebut tidak akan terhapus demi hukum, pencatatan pemblokiran akan tetap berjalan hingga sengketa tersebut selesai dan pemohon mencabut permohonan blokirnya ${ }^{3}$.

\section{Kesimpulan}

Dari hasil penelitian mengenai Kedudukan Pemegang Hak Terhadap Pemblokiran Sertifikat Hak Atas Tanah Oleh Kantor Pertanahan di Kota Semarang dapat disimpulkan bahwa :

1. Faktor-faktor yang menyebabkan pemblokiran terhadap Sertifikat Hak Atas Tanah adalah :

a. Pembagian Harta Gono-Gini

b. Pemegang Hak Atas Tanah tidak Beritikad Baik

c. Pembagian Harta Warisan

d. Sertifikat Hilang

e. Adanya penyidikan dari Pihak Kepolisian

f. Hak Atas Tanah disita jurusita Panitia Urusan Piutang Negara (PUPN) dalam kaitan pelunasan Piutang Negara.

2. Kedudukan Pemegang Sertifikat Hak Atas Tanah saat di lakukan pemblokian dan saat jangka waktu 30 hari pemblokiran habis namun sengketa belum selesai adalah :

a. Kedudukan Pemegang Sertifikat Hak Atas Tanah saat di lakukan pemblokian adalah bagi pemegang hak tidak dapat melakukan perbuatan hukum kepada tanah yang di blokir selama 30 hari semenjak

\footnotetext{
3 Hasil wawancara dengan Lila Trisnaningsi,S.ST selaku Kepala Sub Seksi Pemeliharaan Data dan Hak Tanah dan Pembinaan PPAT Kantor Pertanahan Kota Semarang sebagai narasumber dari Kantor Pertanahan Kota Semarang pada tanggal 8 Juni 2020
} 
pencatatan blokir dilakukan.

Namun kepastian hukum yang sudah di dapat pemegang hak dari peroses pendaftaran tanah tidak akan hilang. Kepastian hukum pemegang hak tetap melekat padanya selama belum ada peralihan hak atas tanah yang dimilikinya.

b. Kedudukan Pemegang Sertifikat Hak Atas Tanah saat jangka waktu 30 hari pemblokiran habis namun sengketa belum selesai adalah Pencatatan Pemblokiran tidak akan hapus demi hukum dan akan tetap berlaku selama tidak ada permohonan cabut oleh pemohon ataupun ketentuanketentuan lain yang menjadi alasan hapusnya blokir sesuai dengan pasal pasal 14 Peraturan Mentri ATR/Kepala Badan Pertanahan Nasional No.13 tahun 2017 tentang Tata Cara Blokir dan Sita, hal ini disebabkan karena di Kantor Pertanahan Kota Semarang belum ada sistem yang dapat mengidentifikasi ataupun menyaring pemblokiran yang sudah daluwarsa sehingga Pencatatan Pemblokiran tetap berjalan sebelum adanya permohonan pencabutan blokir.

\section{Saran}

1. Kepada pembuat regulasi yang dalam hal ini Kementrian Agraria hendaklah agar membuat regulasi tentang masa waktu pemblokiran lebih diperjelas atau di perpanjang untuk mengantisipasi sengketa pertanahan yang tidak dapat diselesaikan dengan segera, dan agar tidak ada ketimpangan antara peraturan/ regulasi dengan Pratik di masyarakat.

2. Dengan Kemajuan Teknologi yang sangat pesat ini Kepada kantor pertanahan semarang hendaklah membuat system yang dapat menyaring dan mengidentifikasi masa berlaku blokir agar sesuai dengan peraturan dan apabila sengketa terhadap tanah tersebut belum selesai namun masa berlaku 30 hari sudah habis hendaklah melakukan peninjauan kembali.

\section{Daftar Pustaka}

\section{Literatur}

Ashofa, B. (2013). Metode Penelitian Hukum. Jakata: Rineka Cipta.

Boedi Harsono, ,. (2013). Hukum Agraria Indonesia Sejarah Pembentukan Undang-Undang Pokok Agraria, Isi dan Pelaksanaanya. Jakarta:

Djambatan. Kadir, M. A. (2004). Hukum dan Penelitian Hukum. Bandung: PT. Citra Aditya Bakti.

M.Arba. (2017). Hukum Agraria Indoesia. Jakarta : Sinar Grafika.

Santoso, U. (2012). Hukum Agraria Kajian Komperehensif. Jakarta: Kencana Prenadamedia.

Suted, A. (2014). Peralihan Atas Tanah Dan Pendaftaraannya. Jakarta: Sinar Grafika.

Syamsudin, M. (2013). Metode Riset Kuantitatif Komunikasi. Jogjakarta: Pustaka Pelajar.

Tehupeiory, A. (2012). Pentingnya Pendaftaran Tanah di Indonesia. Jakarta : Raia Asa Sukses.

\section{Jurnal}

Adhaper. (2015). Tripologi sengketa Tanah dan Penyelesaiannya. Jurnal Hukum Acara Perdata, 55. 
Arinda, A. (2016). Pelaksanaan Peralihan Hak Milik Atas Tanah Melalui Hibah Untuk Anak di Bawah Umur. Repertorium, 30.

Ismail, I. (2011). Sertifikat Sebagai Alat Bukti Hak Atas Tanah Dalam Proses Peradilan. Kanun Jurnal Ilmu Hukum, 26.

Lamila, C. F. (2016). Pewarisan Hak Tanah Warisan. Lex Privatum, 95 .

Larasati, A. \&. (2020). Peralihan Hak Atas Tanah dengan perjanian Jual beli menurut hukum pertanahan Indonesia. Zaaken: Journal of civil and business law, 130.

Mulyadi, S. (2019). Penyelesaian Sengketa Kepemilikan Tanah Bersertifikat Ganda. Jurnal Yuridis , 156.

\section{Perundang-undangan}

Undang-Undang Nomor 5 Tahun 1960 tentang Peraturan Dasar Pokok -Pokok Agraria

Peraturan Presiden Republik Indonesia No. 20 Tahun 2015 tentang Badan Pertanahan Nasional

Keppres Nomor 34 Tahun 2003, Tentang Kebijakan Nasional di Bidang Pertanahan

Keputusan Menteri Nomor Nomor 300/KMK/01/2002 tentang Pengurusan Piutang Negara.

\section{Website}

file://C:/Users/Windows/Documents/tuga s\%20ulfa/paper\%20dian/SKRIPSI/09PERANKEMENTERIAN-ATRBPN-

Sekjen-KementerianATRBPN.pdf di akses pada tanggal 9 Juni 2020 pukul 13:00 